УДК 347.15/17(477)+347.77:004

DOI https://doi.org/10.32837/pyuv.v1i3(28).334

\author{
K.I.Cnacosa \\ https://orcid.org/0000-0002-8126-2306 \\ асистент кафедри иивільного права \\ Національного університету «Одеська юридична академія»
}

\title{
ПОРУШЕННЯ НЕМАЙНОВИХ ПРАВ ІНТЕЛЕКТУАЛЬНОЇ ВЛАСНОСТІ В СОЦІАЛЬНИХ МЕРЕЖАХ
}

Постановка проблеми. 3 огляду на розповсюдження і велику популярність соціальних мереж, таких як Facebook i LinkedIn, та платформ для обміну медіа, таких як YouTube, можна зазначити, що вони дають велику кількість можливостей для власників бізнесу для просування своїх компаній i є ключовою частиною багатьох бізнес-маркетингових стратегій.

Проте зростання важливості соціальних мереж робить деякі нові виклики. Одним з ключових моментів є ризики порушення інтелектуальної власності або порушення прав інтелектуальної власності, що належать третім особам.

Завдяки своїй цифровій природі весь контент в Інтернеті - текст, зображення, аудіо та відео надзвичайно легко копіювати та скачувати. У цьому бінарному середовищі копія та оригінал стають ідентичними поняттями. Найбільша перевага в Інтернеті - швидкі і недорогі розповсюдження даних, для мільйонів користувачів перетворилося на найбільш серйозну проблему в сфері захисту контенту від несанкціонованого копіювання та використання. Традиційні засоби правового захисту в онлайн умовах застосування знайшли своє відображення в деяких сферах захисту, але в інших виявились недостатніми для онлайн існування продуктів інтелектуальної власності.

Інформаційно-комунікаційні технології створили середовище, в якому інформація обертається у вільному доступі, і де об'єкти права інтелектуальної власності існують за законами інформаційними. Ці умови спричинили вільне використання результатів творчості, торгівельних марок та інших інформаційних об'єктів, які можна уособити в загальному терміні «контент» у кіберпросторі. У зв'язку з цим виникає необхідність удосконалення наявної системи регулювання відносин інтелектуальної власності в соціальних мережах [4, с. 9].

Метою статті є визначення цивільних правопорушень немайнових прав інтелектуальної власності в соціальних мережах.

Стан дослідження теми. У зв'язку з тим, що глобальна Мережа розвивається дуже інтенсивно, наукових досліджень 3 питання захисту порушених прав інтелектуальної власності в соціальних мережах явно недостатньо. Разом з тим значна кількість наукових робіт О.П. Радкевича,
Г.І. Грігор'янц, О.О. Мацкевича, О.І Харитонової, Є.О. Харитонова та інших дає можливість скласти загальне враження про досліджуване питання.

Виклад основного матеріалу. Отже, соціальні мережі є майданчиком для порушень прав інтелектуальної власності: авторських прав, прав на торговельні марки тощо. Найпоширенішими видами порушень немайнових прав інтелектуальної власності в соціальних мережах є: незаконне відтворення і копіювання музичних, художніх, літературних творів без попереднього надання на це згоди автором чи правовласником; використання торговельної марки; розміщення HTML-файлу, JAVA-applets, інших файлів, програм, створених іншою особою [5, с. 27-28].

Функціональність соціальних мереж, на відміну від «звичайних» сайтів, передбачає, що користувачі будуть самостійно наповнювати шаблонні сторінки власними творами - текстами, зображеннями, музичними та аудіовізуальними творами. Користувачі соціальних мереж самостійно формують список друзів і передплатників, що може кваліфікуватися як формування бази даних, а також вибирають адресу для сторінки, що має схожість зі створенням засобів індивідуалізації (доменного імені). При цьому адміністрація соціальних мереж намагається зняти з себе відповідальність за дії користувачів та перекласти ї̈ на їх власні плечі. Це легко прослідковується з ліцензійної згоди таких соціальних мереж, як Facebook, Instagram, Вконтакте тощо [6, с. 120].

Згідно з умовами використання соціальної мережі Instagram (розділ «Основні умови», п. 14) користувачі повинні дотримуватися правил спільноти Instagram. А правила користування містять вимогу публікувати тільки ті фото або відео, які користувач створив сам, або ті, якими він має право поділитися:

У п. 4 розділу «Права» зазначається: «Ви підтверджуєте та гарантуєте, що:

- володієте матеріалами, опублікованими вами на сервісі або з його допомогою, або іншими способами;

- володієте правом передавати права та ліцензії, встановлені цими умовами використання;

- публікація та використання матеріалів на сервісі або з його допомогою не порушує $\mathrm{i}$ 
не присвоює права будь-якої третьої сторони, включаючи, крім іншого, право на недоторканність особистого життя, право на публічне використання, авторські права, товарні знаки і (або) інші права на інтелектуальну власність...».

Згідно з п. 8 зазначеного вище розділу «...якщо ваші матеріали порушують справжні умови використання, ви можете понести юридичну відповідальність за розміщення таких матеріалів».

У п. 3 розділу «Повідомлення про порушення авторських та інших прав на інтелектуальну власність» зазначено: «У разі неодноразового порушення прав на інтелектуальну власність інших осіб ми заблокуємо ваш акаунт, якщо вважатимемо це за доцільне» [7].

Політка соціальної мережі Facebook базується на зацікавленості цієї соціальної мережі в допомозі користувачам захищати їх права інтелектуальної власності. Положення про права та обов'язки користувачів Facebook не допускає розміщення матеріалів, що порушують права на інтелектуальну власність третіх осіб, включаючи авторські права і права на знаки товарів і послуг [8, с. 252]. Слід звернути увагу на п. 4 Користувацької угоди, згідно 3 яким деякий контент, котрим користувач ділиться або завантажує, наприклад, фотографії або відео, може бути захищений законами про інтелектуальну власність. Користувач володіє правами на інтелектуальну власність (такими як авторські права або торгові марки) щодо будь-якого такого контенту, який створює і яким діліться в Facebook, та інших використовуваних Продуктах компанії Facebook. Ніщо в зазначеній Угоді не позбавляє користувача прав на контент користувача. Таким чином, користувач має право вільно ділитися своїм контентом з іншими людьми де завгодно. Однак для надання послуг Facebook просить, щоб користувачі надавали юридичні дозволи (відомі як «ліцензія») на використання цього контенту.

Зокрема, п. 5 передбачає, що під час опублікування у Facebook контенту, який є об’єктом прав на інтелектуальну власність, користувач автоматично передає соціальній мережі невиключну, тобто таку, що не вимагає ліцензійних відрахувань та діє по всьому світу, ліцензію з правом передачі та видачі субліцензій на зберігання, використання, поширення, зміну, запуск, копіювання, публічне виконання або показ, переклад контенту і створення похідних робіт на його основі. Дія цієї ліцензії закінчується, коли контент буде видалений з систем Facebook [9]. Щоправда, під сумнівом залишається дієвість такої норми на практиці функціонування соціальної мережі.

Facebook також відмічає, що у зв язку з тим, що закони різних країн можуть відрізнятися, основними нормами права про авторське право та товарний знак є нормативно-правові акти Бюро охорони авторських прав США або Всесвітньої організації з охорони інтелектуальної власності (WIPO) [10].

Своєю чергою ліцензійна угода «ВКонтакте», що виражає погляд адміністратора сайту на проблему авторських прав, формулює умову As Is наступним чином:

«Ліцензіат [Користувач. - Р. Я.] має право $<\ldots>$ відтворювати елементи соціальної мережі у вигляді розміщеної в ній інформації і контенту для особистого використання за допомогою копіювання в пам'ять свого персонального комп'ютера i/або мобільного пристрою (скачування). Якщо ж елементи контенту є об'єктом авторських прав або особистими зображеннями (фотографіями) інших Ліцензіатів або третіх осіб, Ліцензіат зобов'язаний додатково отримувати згоду таких осіб» (п. 4.1.2);

«Ліцензіатові заборонено <...> відтворювати, поширювати, переробляти в комерційних чи некомерційних цілях елементи Соціальної мережі, що є об’єктом авторських прав Ліцензіата, інших Ліцензіатів або третіх осіб, за відсутності дозволу відповідних правовласників на вчинення даних дій» (п. 4.2.1) [11].

Таким чином, «ВКонтакте» формально забороняє будь-яке використання або переробку об'єктів інтелектуальної власності без згоди власників відповідних прав. 3 формальної точки зору до такого використання належить навіть перегляд інформації на сайті, оскільки при цьому виробляється копіювання інформації в пам'ять комп'ютера або мобільного пристрою (кешування) [6, с. 122].

Майже в усіх розглянутих соціальних мережах наявні превентивні саморегулятивні заходи для запобігання порушенням прав інтелектуальної власності та механізми підтримки [8, с. 256], однак транскордонний характер використання об'єктів авторського права іноді приводить до неможливості застосування тих чи інших норм національних законодавств [12, с. 164]. Розглянемо порядок правового регулювання зазначених відносин за національним законодавством.

Згідно зі ст. 423 ЦК України особистими немайновими правами інтелектуальної власності є:

1) право на визнання людини творцем (автором, виконавцем, винахідником тощо) об’єкта права інтелектуальної власності;

2) право перешкоджати будь-якому посяганню на право інтелектуальної власності, здатному завдати шкоди честі чи репутації творця об'єкта права інтелектуальної власності;

3) інші особисті немайнові права інтелектуальної власності, встановлені законом [13].

Як випливає зі статті 435 ЦК України, автором твору науки, літератури чи мистецтва визнається особа, творчою працею якої він створений. За відсутності доказів іншого автором твору вважається фізична особа, зазначена звичайним способом 
як автор на оригіналі або примірнику твору (презумпція авторства) [13].

Перерахування об'єктів авторських прав наведено в статті 433 ЦК України, де зазначено, що об'єктами авторських прав є: літературні та художні твори; лекції, промови, проповіді та інші усні твори; драматичні, музично-драматичні твори, пантоміми, хореографічні, інші сценічні твори; музичні твори (з текстом або без тексту); аудіовізуальні твори; твори живопису, архітектури, скульптури та графіки; фотографічні твори; твори ужиткового мистецтва; ілюстрації, карти, плани, ескізи і пластичні твори, що стосуються географії, топографії, архітектури або науки; переклади, адаптації, аранжування та інші переробки літературних або художніх творів; збірники творів, якщо вони за добором або упорядкуванням їх складових частин $є$ результатом інтелектуальної діяльності; комп'ютерні програми; інші твори [13].

3 вищезазначеного випливає, що для надання захисту новому об'єкту матеріального світу (результату творчої діяльності) необхідно, щоб даний об’єкт був створений творчою працею автора. В цьому разі такий об’єкт буде розглядатися в більш широкому сенсі як результат інтелектуальної діяльності, а в більш вузькому - як твір.

3 розвитком цифрових технологій питання про творчу працю та інтелектуальної діяльності авторів творів в таких сферах, як фото, відео, стає настільки актуальним, що призводить до перегляду раніше існуючих підходів до розуміння творчості, творчої праці та інтелектуальної діяльності.

Відповідно до узгоджених заяв щодо ст. 1 (4) Договору ВОIВ про авторське право [14] та ст. 7, 11, 16 Договору про виконання і фонограми, процес оцифрування ототожнюється з відтворенням, а у Зеленому документі (Green Paper), прийнятому Комісією ЄС 19.07.1995 р., що враховувався під час розроблення зазначених Договорів, визначається, що термін «відтворення» слід застосовувати й у разі застосування цифрових технологій 1022 [15].

Фотографії та інші нерухливі зображення на екрані комп'ютера (карти, схеми, діаграми тощо) $€$ другою категорією поширених творів, які передаються за допомогою соціальних мереж. При цьому ці зображення можуть створюватися на екрані комп'ютера спеціальними програмами, призначеними для полегшення користування людиною самим комп'ютером (операційні системи) та сервісами Інтернету (програми, призначені для «пересування» Інтернетом, - браузери та інші прикладні програми) або бути розміщеними в Iнтернеті і мати незалежний від комп'ютерів користувачів характер. У першому випадку зображення на екрані є частиною комп'ютерної програми, їі інтерфейсом і охороняється разом із усією програмою, а в другому - зображення є цифровою фото- графією і охороняється як звичайна фотографія або є результатом переведення в цифрову форму звичайної фотографії, іншого двовимірного (картини, малюнку) або тривимірного (скульптури, будівлі) твору і за умови відповідності критерію оригінальності охороняється як похідний від них твір [5, с. 28-29].

Якщо поглянути на проблему ширше, то можна відзначити, що в суспільстві вже стали з'являтися думки ще не оформлені як наукові концепції, але при цьому глобальні і революційні за своїм характером, зокрема про те, що процес створення перестав бути актом творчості. Маються на увазі насамперед цифрові фотографії. Обгрунтовується такий висновок тим, що мільйони людей роблять мільйони однакових цифрових фотографій, в результаті чого процес створення перестає бути творчістю; замість цього актом творчості стає процес пошуку і вибору потрібного зображення 3 безлічі подібних. Вважаємо, що це питання буде предметом гострих наукових дискусій у найближчому доступному для огляду майбутньому.

Однак варто з'ясувати, чи можливо об'єктивно визначити наявність творчої праці під час створення цифрової фотографії, зробленої цифровою фотокамерою в автоматичному режимі, або слід констатувати той факт, що всі подібні фотографії не будуть об’єктом авторського права.

В цьому разі науковці схиляються до думки, що рішенням у таких суперечках (у сфері авторства цифрової фотографії (фото- та відеотворів) i наявності творчого характеру) може бути правильний розподіл обов'язків доказування, коли HE фотограф доводить наявність творчої праці, а стороні, яка оспорює наявність творчої праці, потрібно документально спростувати аргумент про те, що фотографія є об'єктом авторського права, таким чином доказавши, що фотографія створена без участі фотографа і / або його творчої праці. Крім того, слід враховувати мету, яка початково лежала в основі створення фотографії під час фотографування - чи збирався він робити фототвори або хотів лише технічно зафіксувати і потім передати інформацію (повідомлення, новини) [16, с. 92-93].

Окрім того, як випливає з міжнародної практики, питання про авторське право автора на фотографії не піддаються сумніву, питання полягає лише в тому, як захистити авторські права, які страждають від копіювання та використання цифрових фотографій у соціальних мережах.

Прикладом захисту зазначених прав є справа щодо отримання компенсації за використання фото без згоди автора гаїтянським фотографом Даніелем Морелем, який на своєму профілі в Twitter розмістив репортажні фотографії подій, пов'язаних з великим землетрусом, що стався на Гаїті в 2010 році. Деякі з цих фото були без його згоди 
опубліковані на обкладинках газет по всьому світу. У зв'язку з таким несанкціонованим використанням суд (Manhattan jury) присудив ФрансПресс та його американському розповсюджувачеві Getty Images сплатити компенсацію фотографу у розмірі 1,22 млн доларів. Однак слід підкреслити, що така ситуація мала місце за кордоном, а як ця ситуація виглядала б в Україні і чи існує судова практика щодо захисту прав інтелектуальної власності в соціальних мережах, невідомо.

Можна зробити висновок, що, незважаючи на деклароване дотримання виняткових прав, соціальні мережі не зацікавлені в тому, щоб впроваджувати технічні засоби захисту прав авторів. При цьому йдеться не тільки про монетизацію творів, а й про механізми захисту прав авторів. На цей час технологія «цифрових відбитків» розвинена досить, щоб блокувати завантаження спірною інформацією на сайті, проте соціальні мережі не поспішають їх впроваджувати, користуючись в тому числі прецедентними судовими рішеннями. Як показав досвід Digital millenium copyright Act, соціальні мережі готові поступитися своїми інтересами лише за умови реальної загрози з боку регулятора; отже, поки впровадження технології «цифрових відбитків» не буде встановлено законодавчо, соціальні мережі продовжать наполягати на технічній неможливості такого впровадження [17].

Таким чином, персональну сторінку в соціальній мережі слід кваліфікувати як складний об'єкт авторського права, який об'єднує в собі піддомени (як засіб індивідуалізації), об'єкти авторських прав (тексти, зображення, аудіовізуальні твори) і базу даних користувачів.

У ситуації, коли спільноти і особисті сторінки є об'єктами виняткових прав користувачів, заборона на розпорядження ними (продаж, дарування, передачу у спадок) суперечить закону, проте практикується адміністрацією соціальних мереж. Відповідно до ст. 440 ЦК України правовласнику належить виключне право використовувати твір у будь-якій формі і будь-яким способом, і з боку соціальної мережі не може йтися про заборону будь-якого використання або тим більше про знищення самого твору (спільноти) як санкції [13].

Висновки. На підставі проведеного дослідження вбачається за необхідне введення спеціального законодавчого регулювання соціальних мереж, що дозволить передусім захистити права користувачів щодо розпорядження ними своєю інтелектуальною власністю. Однак такий закон не повинен встановлювати каральні санкції, обмежувати доступ до соціальних мереж у зв'язку з віковим цензом або іншими особистісними приналежностями.
Тобто майбутнє регулювання має насамперед вирішувати приватноправові питання функціонування соціальних мереж, а не завдання патріотичного виховання і національної політики.

\section{Jimepamypa}

1. Council Directive 91/250/EEC of 14 May 1991 on the legal protection of computer programs. URL: https://eur-lex.europa.eu/legal-content/EN/TXT/ ?uri $=$ CELEX $\%$ 3A31991L0250.

2. Про авторське право і суміжні права : Закон України від 04.11.2018 Відомості Верховної Ради України $($ ВВР ). 1994. № 13. Ст. 64.

3. Ріппа П.С. Забезпечення авторських прав у мережі Інтернет. URL: http://www.nbuv.gov.ua.

4. Будник Р.А. Эволюция системы авторских смежных прав в информационном обществе: от исключительного к инклюзивному праву автора. Москва : Юрлитинформ, 2013. 192 с.

5. Актуальні проблеми цивілістики у цифрову добу: онлайнові соціальні мережі : монографія / за ред. Є.О. Харитонова, О.І. Харитонової; укл. Б.В. Фасій ; НУ ОЮА. Одеса: Юридична література, 2018. 176 с.

6. Янковский Р.М. Социальные сети: Вопросы защиты исключительных прав пользователей. Право интеллектуальной собственности: Сб. науч. тр. / отв. ред. Афанасьева Е.Г. Москва, 2017. С. 119-131.

7. Нарушение авторских прав в Instagram. URL: https://sion.ua/ru/narushenie-avtorskih-prav-vinstagram/.

8. Фасій Б.В. Захист прав та інтересів у соціальних мережах. Актуальні проблеми інтелектуального, інформаційного та IT права: мат. 2 Всеукр. Наук.-прaкт. конф. (Львів, 27-28 жовтня 2017 року). Львів : Юрид. фак.-т Львів.нац.ун-ту. ім. І. Франка, 2017. C. 252-257. C. 252.

9.Користувацькаугода.URL:https://www.facebook. com/legal/terms.

10. Авторське право. URL: https://www.facebook. com/help/1020633957973118/?helpref=hc_fnav.

11. Лицензионное соглашение «ВКонтакте». 2019. URL: https://vk.com/licence.

12. Думчиков М.О. Проблемні аспекти охорони й захисту права інтелектуальної власності в Мережі Інтернет. Філософія права. 2019. С. 164-166.

13. Цивільний кодекс України : Кодекс від 16 січня 2003 року (Редакція станом на 31.03.2019). Відомості Верховної Ради України (ВВР). 2003. №№ 40-44. Ст. 356.

14. Договір Всесвітньої організації інтелектуальної власності про авторське право, прийнятий Дипломатичною конференцією 20 грудня 1996 року. URL: https://zakon.rada.gov.ua/laws/show/995_770.

15. Авторське право i суміжні права в інфоромаційному просторі: «Зелений документ», прийнятий Комісією Європейського Співтовариства 19.07.1995 p. URL: http://litterref.ru/qasujgmermer.html.

16. Вешкурцева 3.В. Защита нематериальных благ и личных неимущественных прав: основные современные проблемы и пути их решения. Юридические исследования. 2017. URL: author.nbpublish.com.

17. Digital Millennium Copyright Act. URL: https://uk.wikipedia.org/wiki/Digital_dMillennium_ Copyright_Act. 


\section{Анотація}

Спасова К. I. Порушення немайнових прав інтелектуальної власності в соціальних мережах. - Стаття.

У зв'язку з тим, що глобальна Мережа розвивається дуже інтенсивно, наукових досліджень 3 питання захисту порушених прав інтелектуальної власності в соціальних мережах явно недостатньо. Тому в статті ми спробували визначити найпоширеніші види порушень немайнових прав інтелектуальної власності в соціальних мережах. Проаналізовано превентивні саморегулятивні заходи для запобігання порушенням прав інтелектуальної власності та механізми підтримки. Розглянуто порядок правового регулювання зазначених відносин за національним законодавством.

Проаналізовано питання про творчу працю та інтелектуальну діяльність авторів творів в таких сферах, як фото, відео, яке є настільки актуальним, що призводить до перегляду раніше наявних підходів до розуміння творчості, творчої праці та інтелектуальної діяльності.

Зазначено, що, незважаючи на деклароване дотримання виключних прав, соціальні мережі не зацікавлені в тому, щоб впроваджувати технічні засоби захисту прав авторів. При цьому йдеться не тільки про монетизацію творів, а й про механізми захисту прав авторів. На цей час технологія «цифрових відбитків» розвинена достатньо, щоб блокувати завантаження спірної інформації на сайті, проте соціальні мережі не поспішають їх впроваджувати, користуючись в тому числі прецедентними судовими рішеннями.

За підсумками проведеного дослідження зроблено висновки щодо необхідності введення спеціального законодавчого регулювання соціальних мереж, що дозволить передусім захистити права користувачів щодо розпорядженнянимисвоєюінтелектуальноювласністю.

Ключові слова: цивільне право, IT-право, соціальні мережі, немайнові права, права інтелектуальної влас- ності, Інтернет, Мережа, порушення прав автора, порушення права на зображення.

\section{Summary}

Spasova K. I. Violations of non-property rights of intellectual property in social networks. - Article.

Due to the intensive development of the Global Network, there is clearly insufficient research on the protection of IPRs in social networks. Therefore, the article attempts to identify the most common types of infringements of non-proprietary intellectual property rights in social networks. Preventive self-regulatory measures to prevent IPR infringement and support mechanisms have been analyzed. The procedure of legal regulation of these relations under the national legislation is considered.

The article deals with the creative work and intellectual activity of the authors of works in such fields as photography, video, which is so relevant that it leads to the revision of the existing approaches to the understanding of creativity, creative work and intellectual activity.

It is noted that, despite the declared respect for exclusive rights, social networks are not interested in implementing technical means of protecting the rights of authors. In this case, it is not only about the monetization of works, but also about the mechanisms of protecting the rights of authors. At present, digital fingerprint technology is developed enough to block the downloading of contentious information on the site; however, social networks are in no hurry to implement them, including through case law.

Based on the results of the study, it was concluded that it is necessary to introduce a special legislative regulation of social networks, which will first of all protect the rights of users to dispose of their intellectual property.

Key words: civil law, IT law, social networks, non-property rights, intellectual property rights, Internet, Network, copyright infringement, image rights infringement. 